\title{
دراسة بكتريولوجية وكيميائية لمياه الاسالة والذزانات في بعض أحياء مدينة بغداد
}

\author{
ياسمين رعد عبد النافع و شهاب احمد سلمان \\ قسم علوم الحياة ، كلية العلوم ، جامعة بغداد.
}

الخلاصة

أجريت هذه الدر اسة في بعض أحياء مدينة بغداد لغرض تقييم محتو اها من البكتريا وقد أختريت 6 مناطق من جانب الكرخ

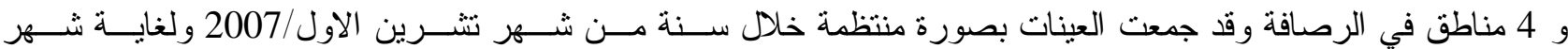
أيلول2008.

أظهرت النتائج ارتفاع العدد الكلي للبكتريا وبكتريا القولون في نماذج مياه الخز انات مقارنةً بمياه الإسالة المنزليــة خــلد

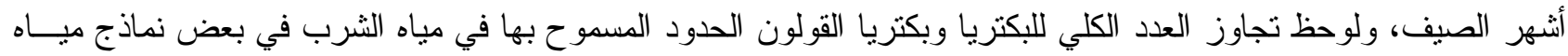

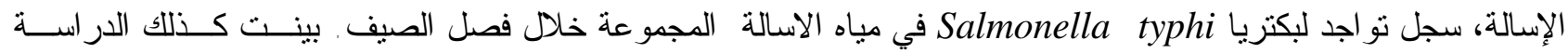

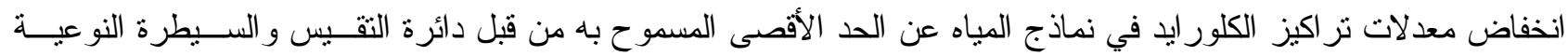

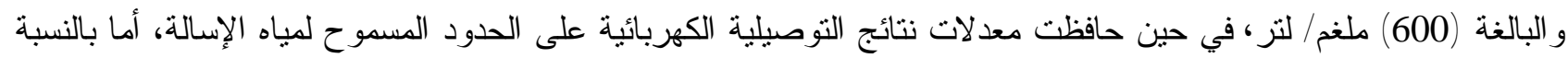
لمياه الخزانات المنزلية فقد تجاوزت الحدود السموح بها إذ بلغتاعلى معدل لها (2295) مايكروسيمنز /سم في جانب الكرخ. الادالة على تلوث المياه بالمو اد البرازيـــة(5)، و أن بكتيريـــا المقدمة

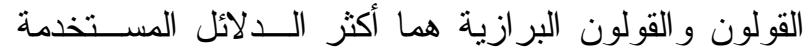

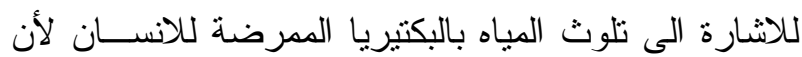
وجودها يشير إلى وجود كائنات ممرضة للإنسان، وان مدة لهان بقاءها أطول من مدة بقاء الأحياء الممرضة الأخـــى (6). إن عدم وجود بكتيريا القولون في الماء لا يعني سلامة الماء الهاء وصلاحيته (7)، حيث توجد فيروسات في ميــاه الثــرب لفرباه بالر غم من خلو ها من بكتيريا القولون و هذا يعود إلى مقاومة

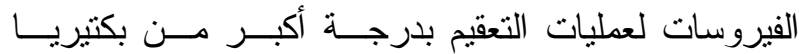

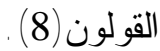

يعد استخدام مياه الثرب الملوثة بشكل منكرر يـؤدي إلى ارتفاع نسبة وقوع الأمر اض(9)، لذلك وضعت المعايير

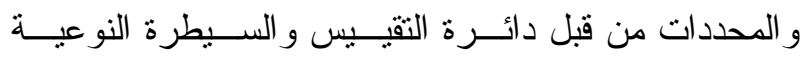

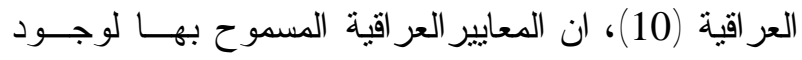

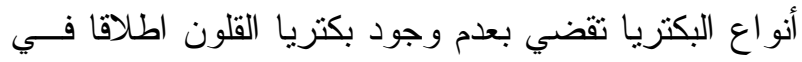

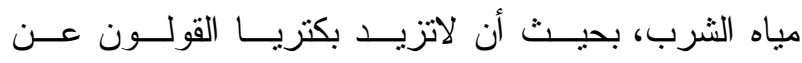

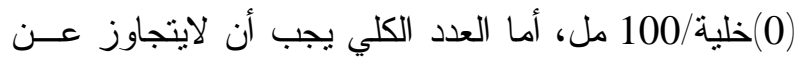

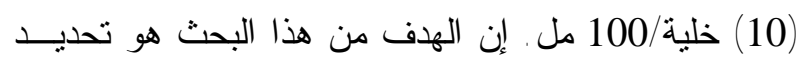

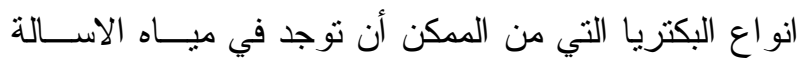

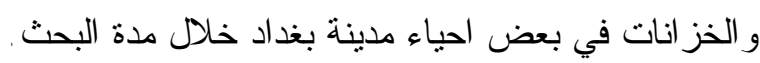
يعد الماء الدعامة الاساسية لمظاهر الحياة وتو افره هــو

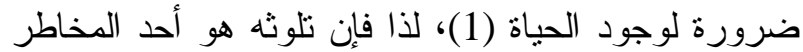

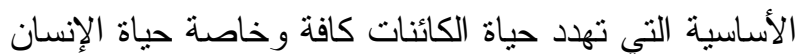
منها، لذلك يجب أن تكون مياه الثرب خالية من الملوثــات الكيميائية و الفيزيائية والاحيائية، وأن تكون المياه مسنساغة

بكونها عديمة اللون و الطعم و الر ائحة (2).

الهتمت منظمة الصحة العالمية ووكالة حمايــة البيأسـة

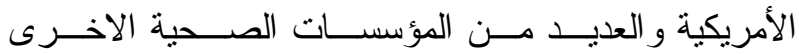

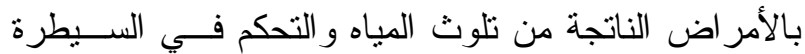
عليها(3).

إن قضية جودة مياه الخز انات المنزلية و الاعتماد عليها لتوفير احتباجات السكان اليومية المختلفة، هي من الأمــور

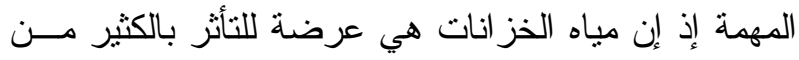
العو امل البيولوجية و العضوية وغير ها التي تئدي إلى تلوهي

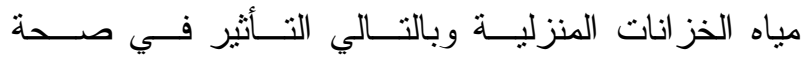

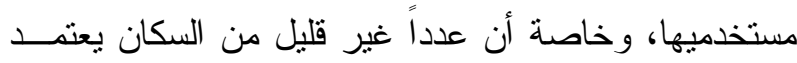

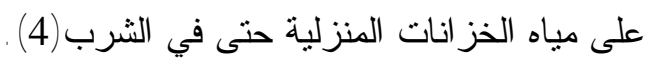
يعد المجموعة القولونية (Coliform) التي تعود للعائلة المعوية (Enterobacteriaceae) من أبرز أنو اع البكتيريا نيا لنديا 
النتائج

تم تسجيل نو اجد ل اربع انو اع من البكتريا في كل من ماء الخز انات في جانبي بغداد (الرصافة و الكر خ/ بغـــداد). كما تم تسجيل نو اجد لخمس انو اع من البكتريسـا فــي مـــاء

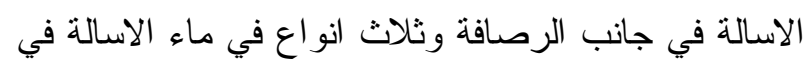

جانب الكر خ من بغداد، جدول(1) )

$$
\text { جدول (1) }
$$

الأجناس والأنواع البكترية المعزولة (جانبي الرصافة و الكرخ/ بغداد).

\begin{tabular}{|c|c|}
\hline 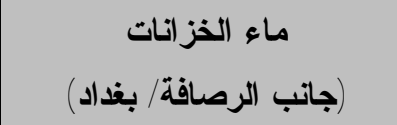 & 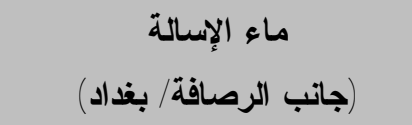 \\
\hline Escherichia coli & Escherichia coli \\
\hline Enterobacter aerogenes & Enterobacter aerogenes \\
\hline Klebsiella pneumonia & Klebsiella pneumonia \\
\hline \multirow[t]{2}{*}{ Pseudomons aeruginosa } & Salmonella typhi \\
\hline & Pseudomonas aeruginosa \\
\hline (جانب الكرخ/ بغداد) & (جانب الكرخ/بغداد) \\
\hline Escherichia coli & Escherichia coli \\
\hline Enterobacter aerogenes & Enterobacter aerogenes \\
\hline Klebsiella pneumonia & Klebsiella pneumonia \\
\hline Pseudomonas aeruginosa & \\
\hline
\end{tabular}

تتفق نتائج البحث للعز لات البكتيرية مع ماتوصل اليـــ

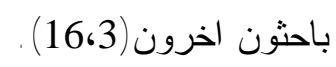

\section{Cloifrom Bacteria بكتريا القولون}

تر اوحت معدلات بكتريا القولون لمياه الإسالة و الخز انات

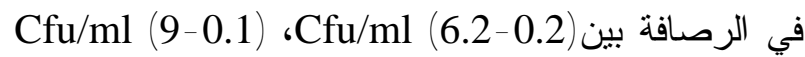
على التوالي، حيث سجلت أدنى قيمة لبكتريا القولون لميــاه

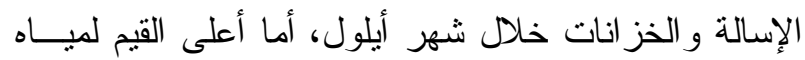

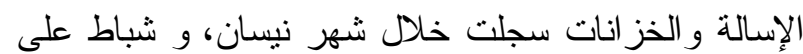
التو الي، يوضـح الثكل(1) إلى وجود نغاير فــي معـــلات

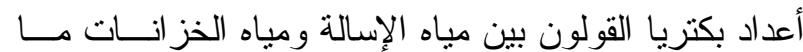

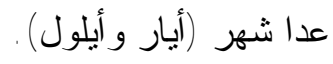

طر ائق البحث والمواد المستعملة جمع العينات

جمعت (303) عينة اسبو عيا من مناطق الدراسة ابتداء

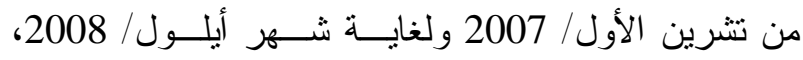

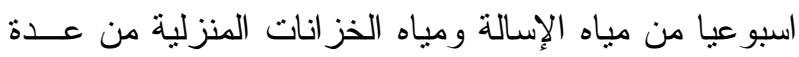

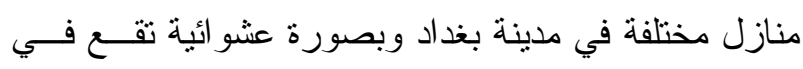
جانبي الكرخ و الرصافة بحيث تمثل إلى أقصى حد مدكـن فئن

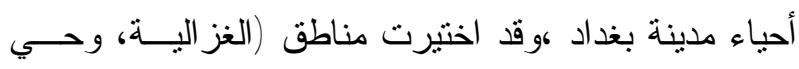
الخضر اء، وحي الجهاد، ونفق الثرطة، والبياع، والدورة)

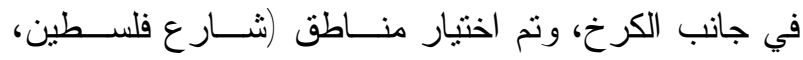

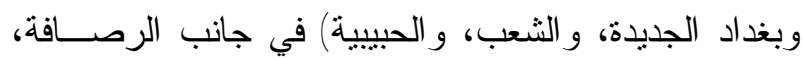
وقد روعي في أخذ العينات على أن تكون عشوائية وكانت أعدادها منقاربة قدر الإمكان .

الاوساط الزرعية

أستعملت الاوساط الزرعية المناسبة لتتمية بكتريا المياه

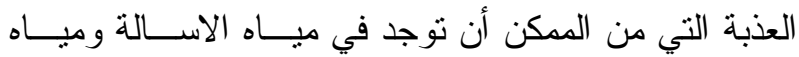

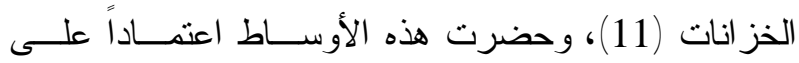

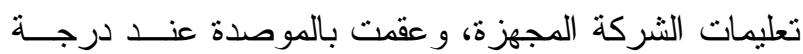

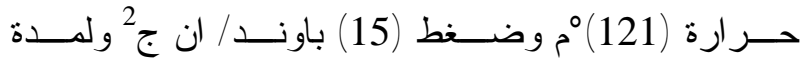
(15) - (15) دقيقة.

أجريت الفحوصات المجهرية و الكيموحيويــة اعنمــاداً

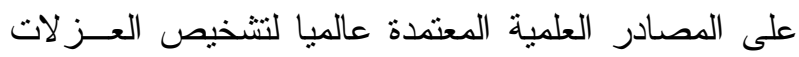

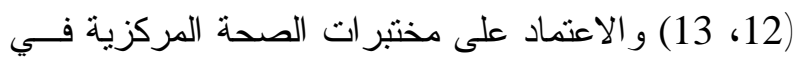
عزل ونتخيص بعض الانو اع من البكتري. الفحوصات الفيزيائية والكيميائية للمياه

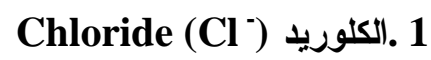
تم قياس تركيز الكلوريد حسب الطريقة المتبعــة مــن الجمعية الأمريكية للاختبار ات و الطر ائق (14) . 2. قابلية التوصيل الكهربائي تم قياس قابلية التوصيل الكهربائي لعينات حسب طريقة 


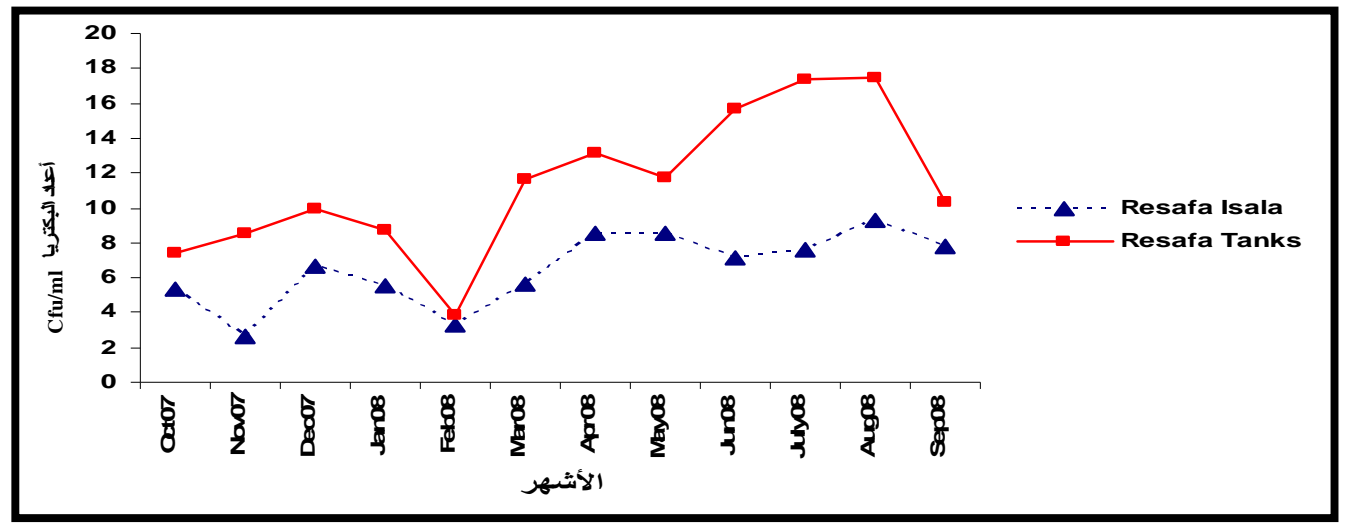

شكل (1) معدلات أعداد بكتريا القولون (cfu/100 ml) لمناطق الدراسة لمياه الإسالة والخزانات (جاتب الرصافة/ بغداد).

خلال شهري أيار و أيلول، أما أدنى قيمة لميــاه الخز انــات

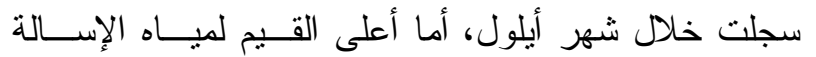
و الخز انات سجلت خلال شهري كــانون الأول، و كــانون
يوضتح الثكل(2) أن قيم أعداد بكتريا القولـــون لميــاه

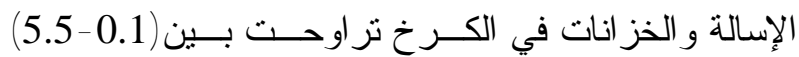

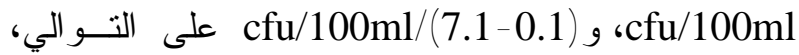
حيث سجلت أدنى قيمة لأعداد بكتريا القولون لمياه الإســالة

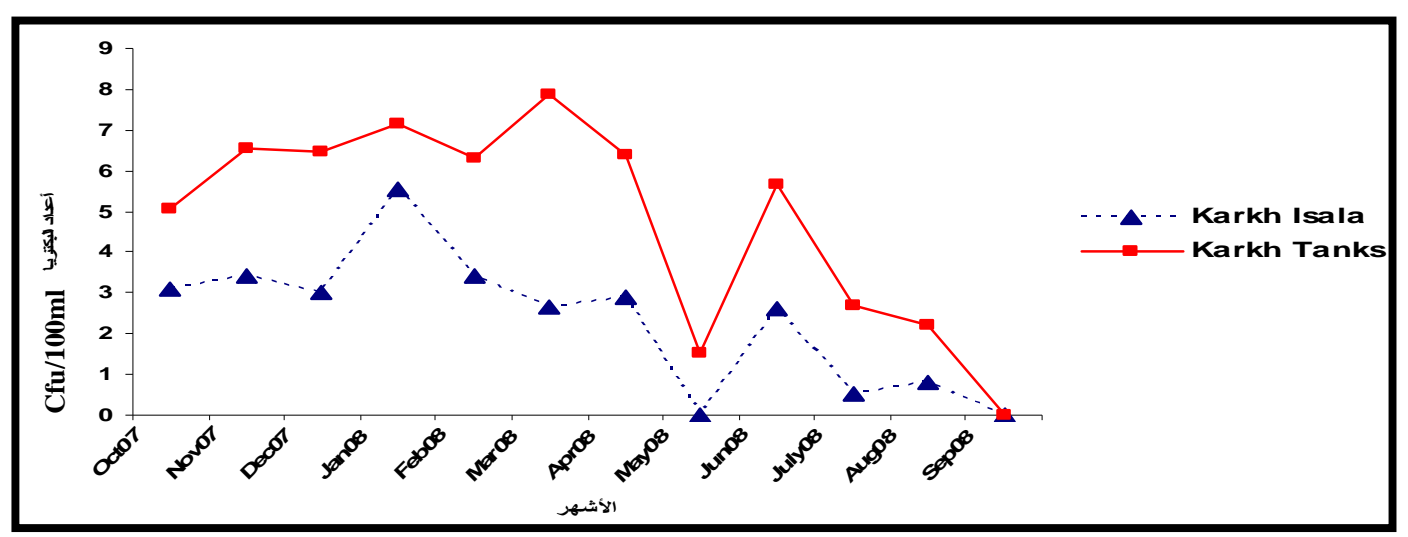

شكل (2) معدلات أعداد بكتريا القولون (cfu/100 ml) لمناطق الدراسة لمياه الإسالة والخزانات (جاتب الكرخ/ بغداد).

خطير اً حيث يجب أن يخلو ماء الثرب من أية خلية لبكتريا القولون في 100 مل(10).

Total Bacterial Count العدد الكلي للبكتريا

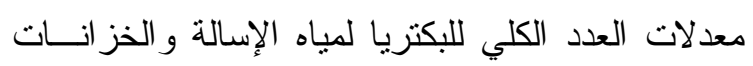
و ccfu/ml (9.3-2.6)

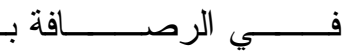

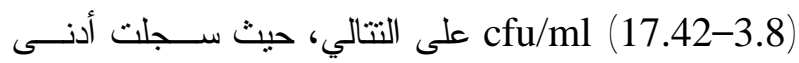

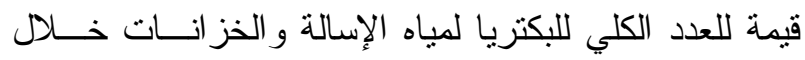

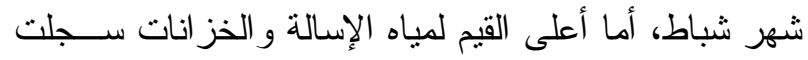

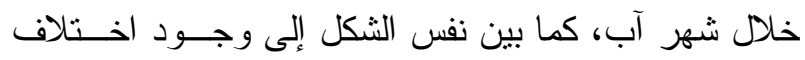

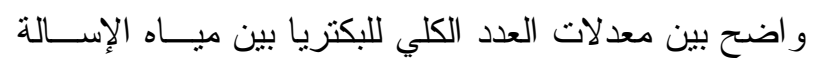

إن ازدياد أعداد بكتريا القولون للأنو اع المدروسة لاسيما

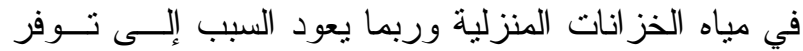
الظروف الملاعمة لنمو وتكاثر البكتريا فــي حالــة تـــو افر

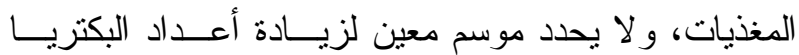

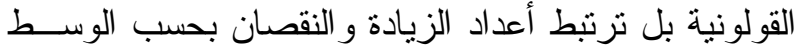
التي تعيش به ووفرة المغذيات الملاءمة لنموهــا(17). إن وجود بكتريا القولون في مياه الثرب يشير إلى عدم معاملة المياه بصورة صحيحة، أو أن المنظومة العاملة ذات جودة متدنية أو نتيجة تردي نوعية المياه (المصدر المجهز للمياه)

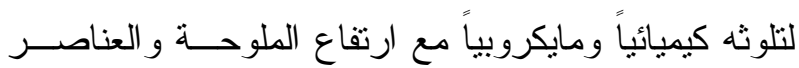
النقيلة (18).إن تلوث الماء ببكتريا القولون يعـــ مؤثــراً 


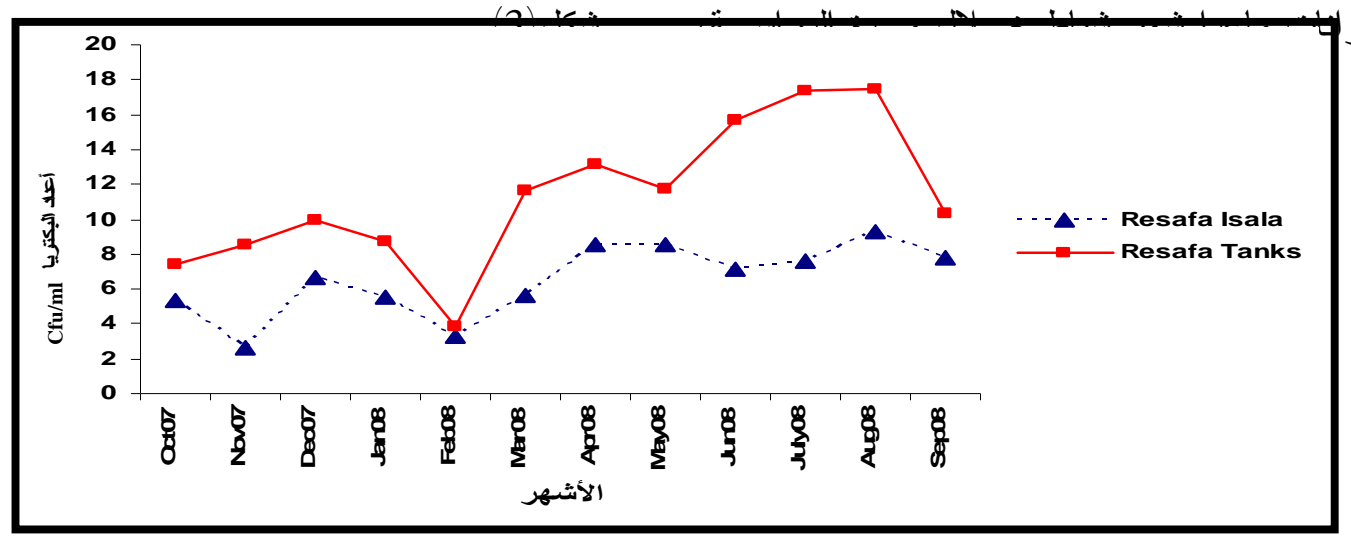

شكل (3) معدلات أعداد البكتريا الكلية (cfu/ml) لمناطق الدراسة لمياه الإسالة و الخزانات (جاتب الرصافة/ بغداد). لمياه الإسالة و الخز انات خلال تشرين ألاول، أما أعلى القيم الثكل (4) أن قيم العدد الكلي للبكتريا لميــاه الإســالة

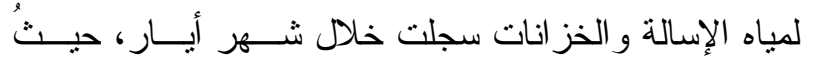

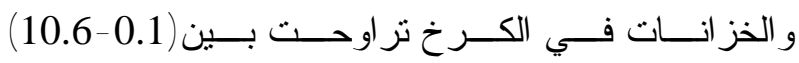
يشير الثكل إلى وجود اختلاف و اضـح بين معســلات ميــاه ع cfu/100ml/(15.8 - 3.6) و cfu/100ml التو الي، حيث سجلت أدنى قيمة لأعداد العدد الكلي للبكتريا الإسالة و الخز انات خلال جميع اثثر السنة.

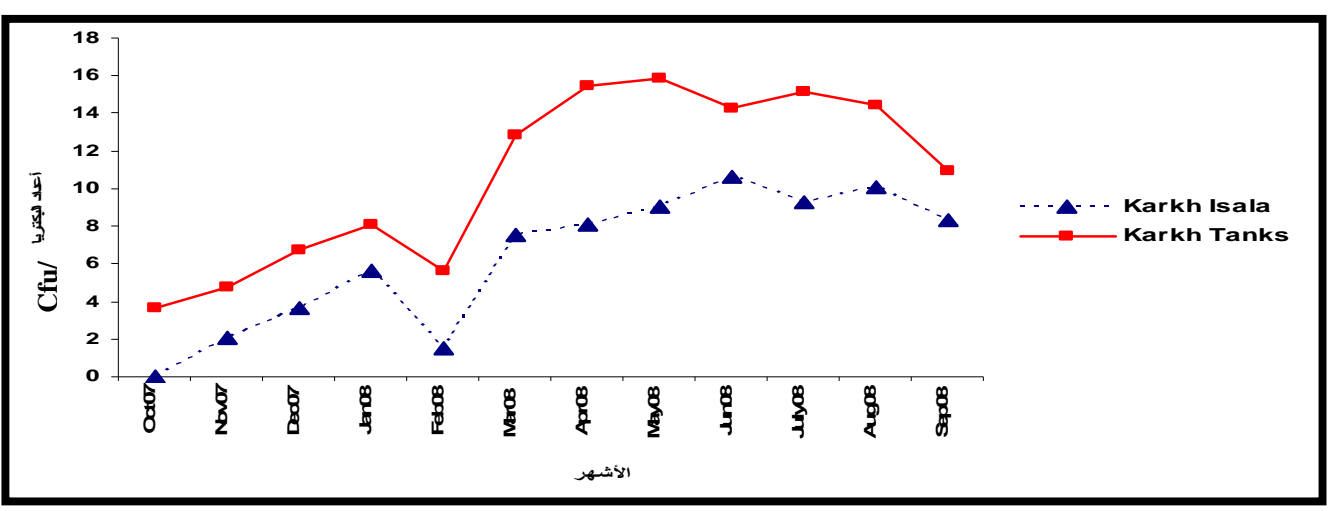

شكل (4) معدلات أعداد البكتريا الكلية (cfu/ml) لمناطق الدراسة لمياه الإسالة والخزانات (جاتب الكرخ/ بغداد).

نشاط الابتدائيات (Protozoa) و التي تعد مــن المغـذيات الأساسية للبكتريا ولهذا تتخفض أعدادها.

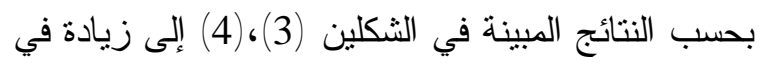

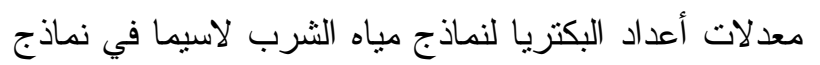

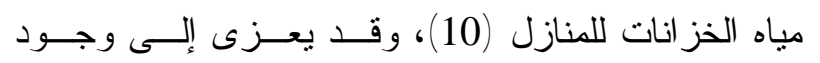

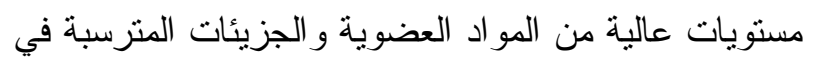

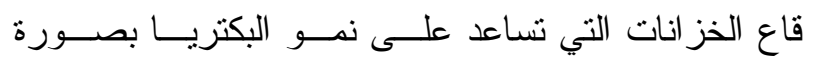

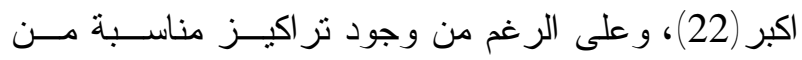

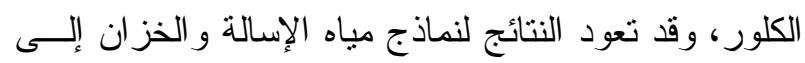

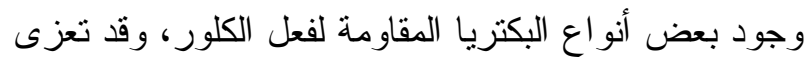

يتضح من النتائج أن التغيير ات الحاصلة فـي معــلات العدد الكلي للبكتريا لمناطق الدراسة الموضحة في الثكلين

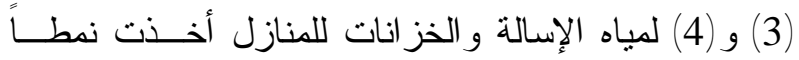

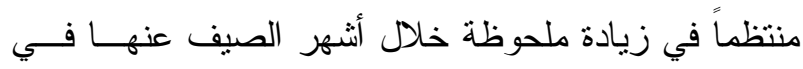

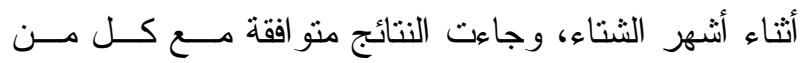

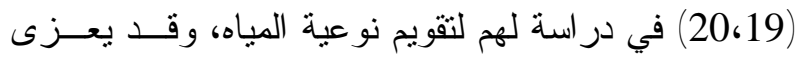
سبب الارتفاع الأعداد البكتيرية إلى انخفاض منسوب نهــر

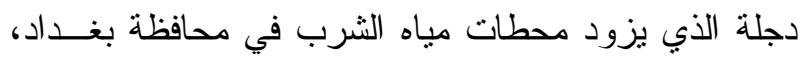

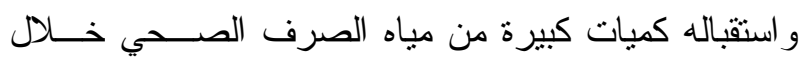

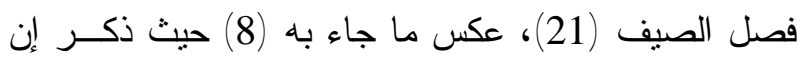
زيادة درجات الحرارة صيفاً و التي بدور ها تؤدي إلى زيادة بهاء 


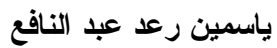

تز اوحت معدلات الكلوريد لميــاه الإســالة و الخز انــات

سبب المقاومة إلى حدوث طفر ات ور اثية للبكتريا تمكنها من

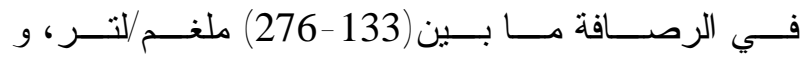

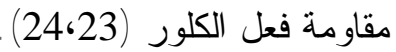

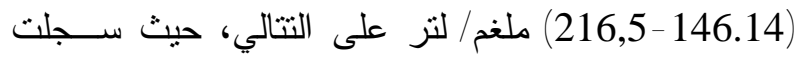

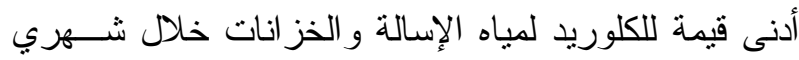

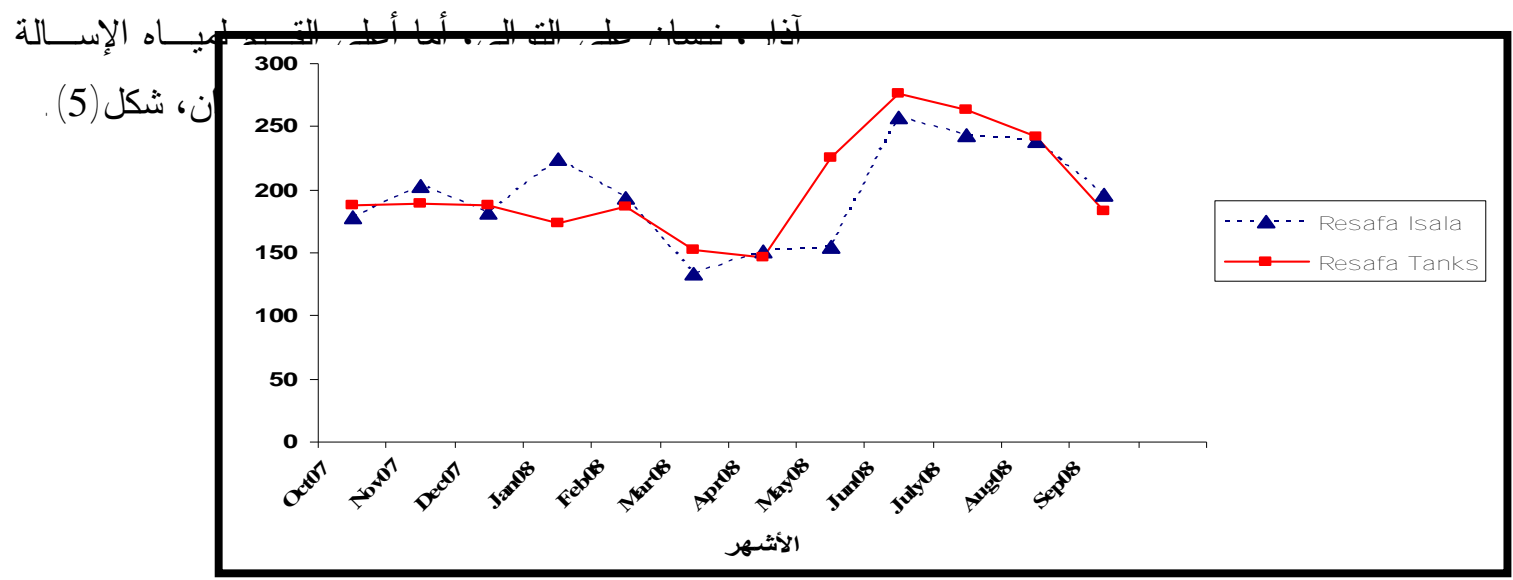

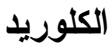

شكل (5) معدلات قيم الكلوريد (ملفم/لتر) لمناطق الاراسة لمياه الإسالة والخزانات

(جانب الرصافة/ بغداد) خلاد مدة الدراسة.

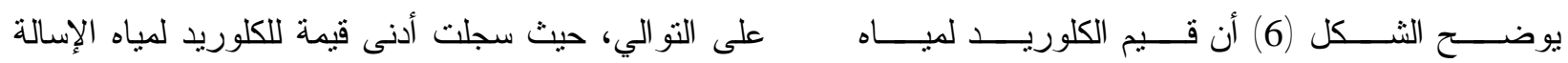

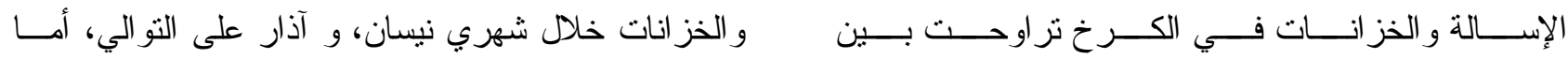

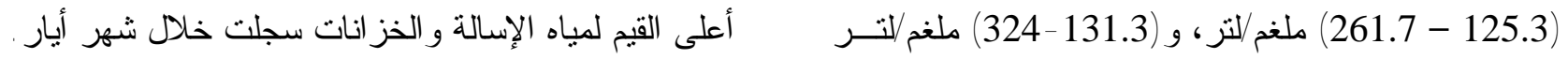

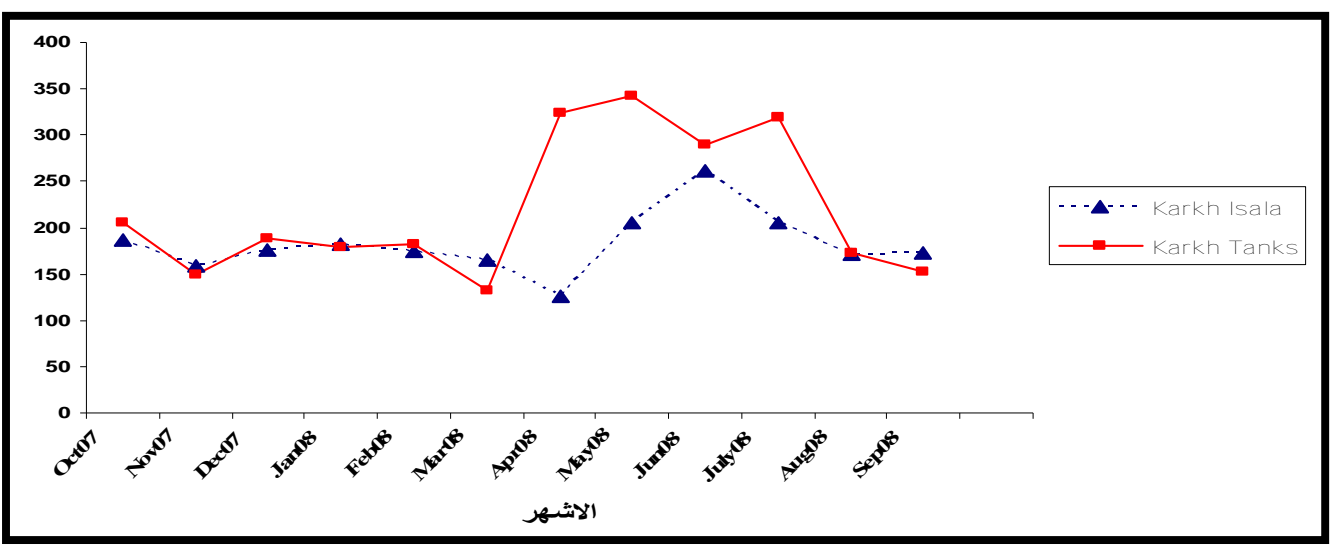

شكل (6) معدلات قيم الكلوريد (ملفم/لتر) لمناطق الدراسة لمياه الإسالة والخزانات (جاتب الكرخ/ بغداد) خلا مدة الدراسة.

المياه(22)، و الذي يفقد بارتفاع درجات الحــر ارة وخــلدل

التخزين (25).

مما يضيف بعض أصــــاب المنــازل أقر اصـــا مــن

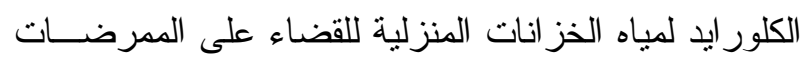

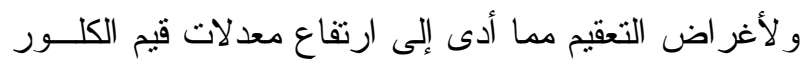

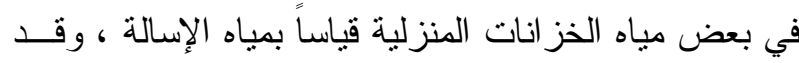

يتبين أن هنالك اختلافاً لمعدلات قيم الكلور في منــاطق

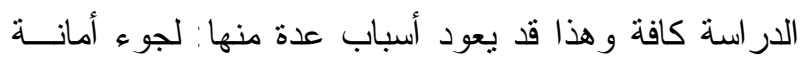
بغداد إلى زيادة كميات الكلور المضافة في مثـــاريع ميــاه

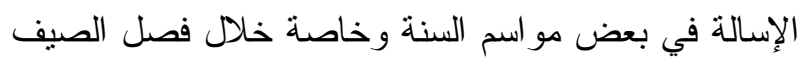

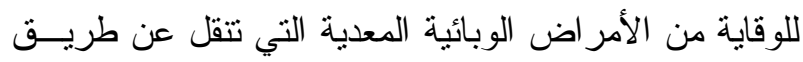


Electrical Conductivity التوصيلية الكهربائية تر اوحت معدلات قيم التوصيلية الكهربائية لمياه الإسالة

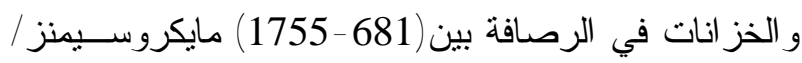
سم و (696 -1723) مايكروسيمنز / سم على التو الي، حيث سجلت أدنى قيمة توصيلية كهربائية لمياه الإسالة و الخز انات خلال شهري كانون الثاني، وشباط على التو الي، في حــين

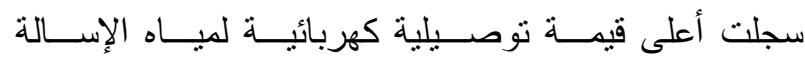
و الخزانات خلال شهر أب، شكل (7) . كما يوضح الثـــل معدلات القيم التوصلية الكهربائية كانت متقاربة ما بين مياه

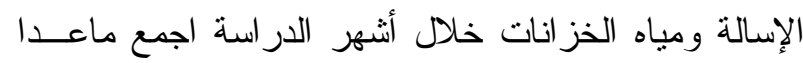

لوحظ كذلك ارتفاعه في بعض مناطق الدر اسة دون غيرها،

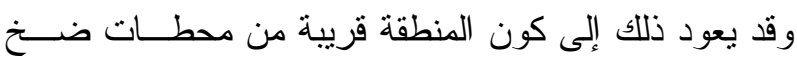

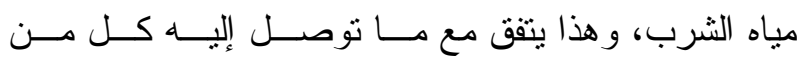

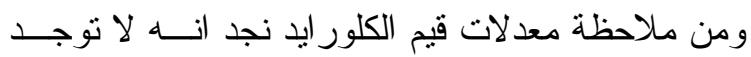

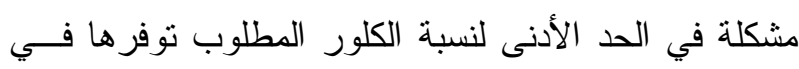

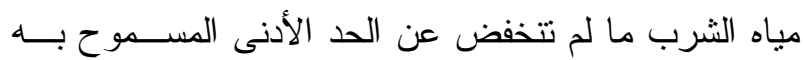

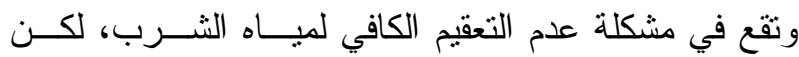
بالمقابل نجد أن متوسط معدلاتها في بعض مناطق الدار استة

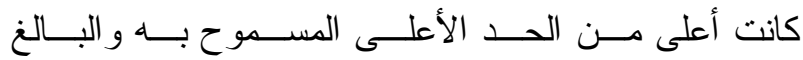

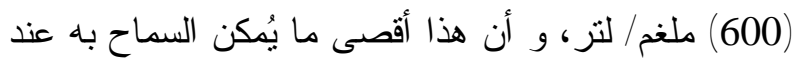

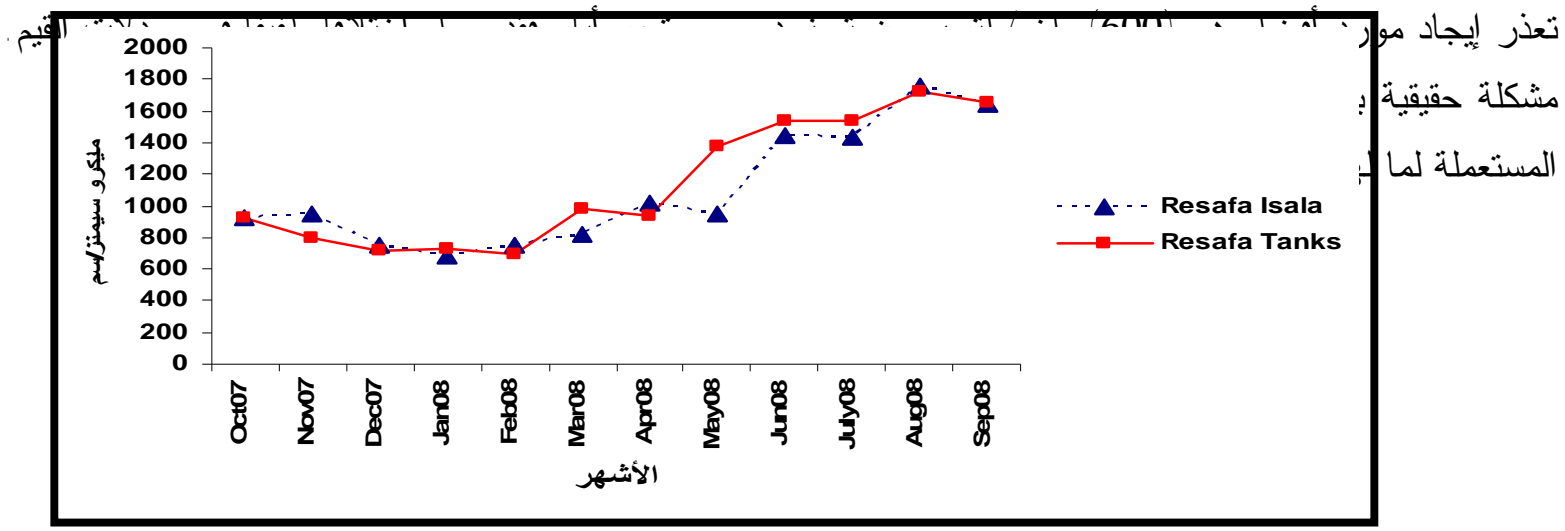

شكل (7) معدلات قيم التوصيلية الكهربائية (مايكروسيمنز/سم) لمناطق الاراسة لمياه الإسالة والخزانات (جانب الرصافة/ بغداد) خلاد مدة الدراسة.

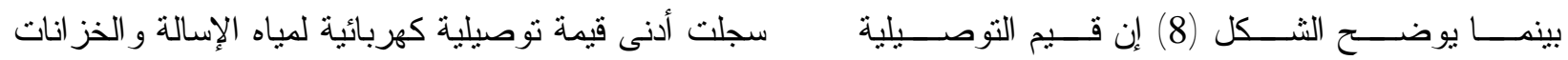

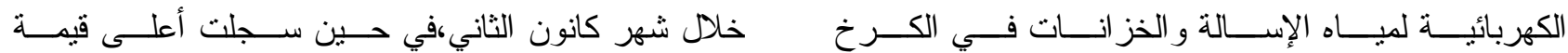

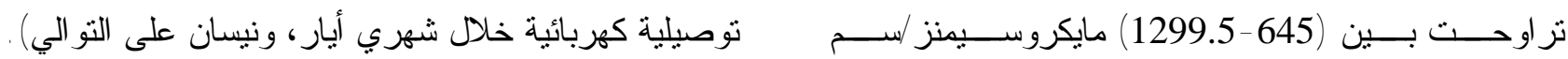

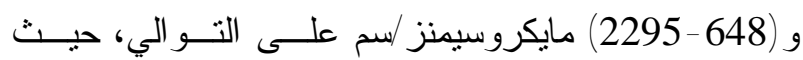

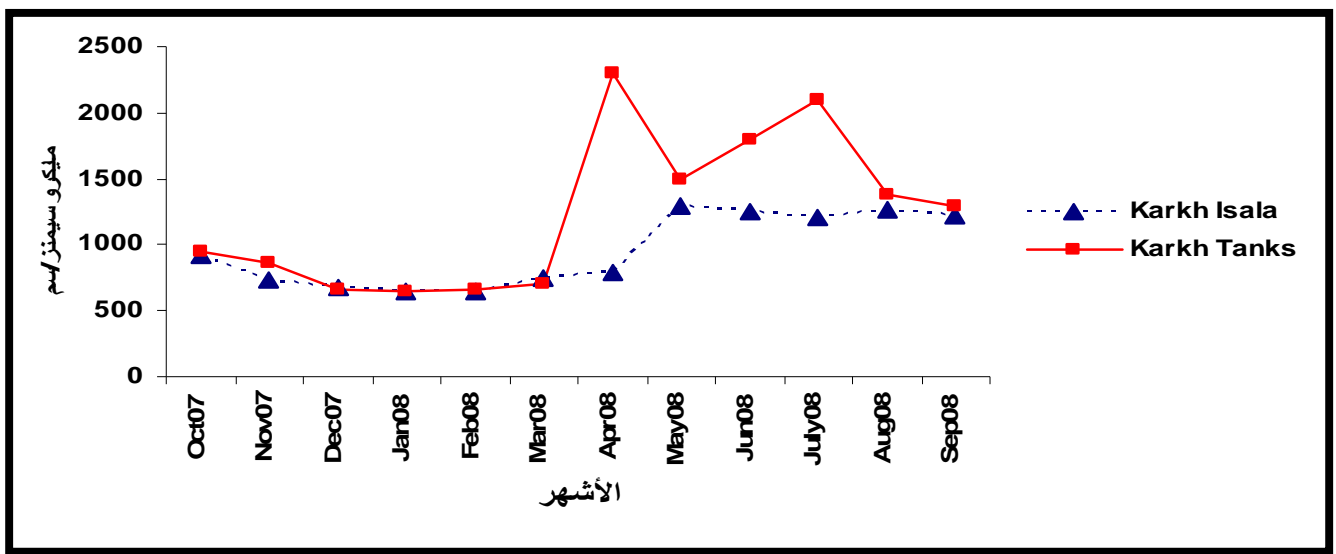




\section{شكل (8) معدلات قيم التوصيلية الكهربائية (مايكروسيمنز/سم) لمناطق الدراسة

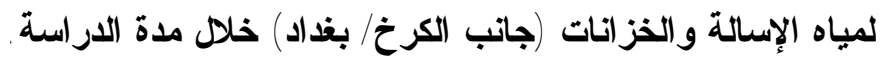

أطروحة دكتور اه، كلية العلوم، جامعة بغداد، .2007

[3] الجبوري، علي حسون ادهام. دراسة الدلائل

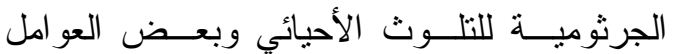
الفيزيائية و الكيميائية عليها لمياه نهر دجلة ونهر الزاب الأسفل في مدينة الحويجة وتكريت، رسالة ماجستير ، كلية التربية، جامعة تكريت، 2005.

[4] (WHO), World Health Organization Assessing Microbial Safety of Drinking Water. IWA Publishing, Alliance House, London, UK, 2003, 295 P.

[5] N. J. Ashbolt, W. O. Grabowand In: M. Snozzi. Indicators of Microbial Water Quality.(L. Fewtrell; J. Bartram, (Eds.)), Water Quality. Guidelines, Standards and Health World Health Organization and IWA, London, UK, 2001, Pp. 216-289.

[6] (USEPA), U. S. Environmental Protection Agency Microbial Source Tracking Guide Document. Office of Research and Development, Washington, DC EPA-600/ 064, 2005, Pp. 131.

الثبيب، أسفار شهاب . المياه و الملوثات المجهرية

وز ارة التقافــة و الأعــلام، الـــدار الوطنيـــة للنشر

$$
\text { و الاعلان، }
$$

[8] الثواني، طاووس محمد كامل أحمد. دراسة بيئية ومايكروبيولوجية لنهر الزاب الأسفل في منطقة النون كويري إلى الحويجة، محافظة التأميم. رسالة ماجستير ، كليـــة التزبيـــة للبنات، جامعـــة تكريت، .2001

[9] المو اصفة القياسية رقم (417) الجزء الأول. وزارة

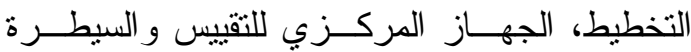

$$
\text { النو عية، الجمهورية العر اقية، } 2001 .
$$

[10] J. A. Aziz, Management of Source and Drinking-Water Quality in Pakistan. Eastern Mediterranean Health Journal, Vol. 11, No. (5 \& 6), 2005.

[11] المصلح، رشيد محجوب،علم الأحبـــاء المجهريـــة دهـة

للمياه. بيث الحكمة، جامعة بغداد، العراق،1988 .

تشير نتائج الدارسة إلى أن لمياه الإسالة تأثنير أ كبير ا في مياه الخزانات المنزلية كما مبين في الثكل (7) و (8)، وقد يعود سبب ذلك إلى أن سرعة استهلاك مياه الخزانات فـي

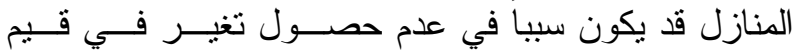
التوصيلية الكهربائية بين نماذج مياه الإســالة و الخز انـات للمنازل نفسها (22).

يلاحظ من نتائج هذه الدراسة ان معدلات قيم التوصلية

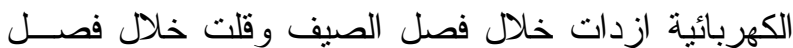
الثتاء، ويتفق هذا مع ماتوصل إليه (28)، وقد يعود ذلـــــ

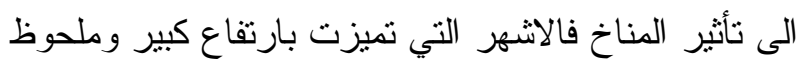

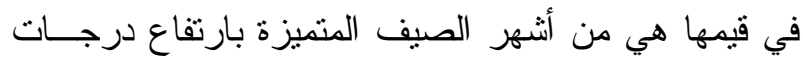

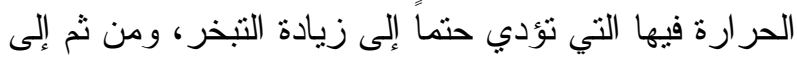

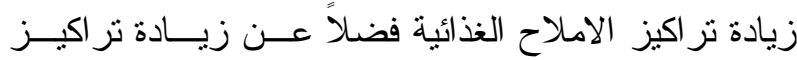

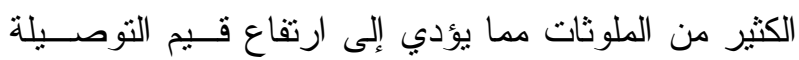

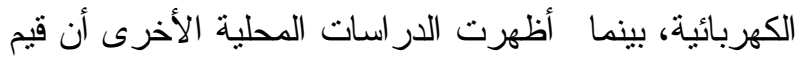
التوصيلة الكهربائية ترتفع خلال فصل الثتاء، وهذه النتائج لا تتفق مع كل من الباحثين(8) و (2) لنماذج المياه العذبـــة التي تميزت بارتفاع قيم التوصيلة الكهربائية خلال اثنــر

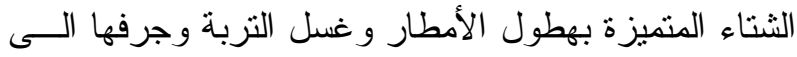
النهر مما يساعد على زيادة قيمة الاملاح الذائبة في الماء. هنا لابد من الإشارة إلى عدم وجود قيمة محددة للتوصـيلة الكهربائية في نماذج ماء الثرب من قبل اية منظمة عالمية،

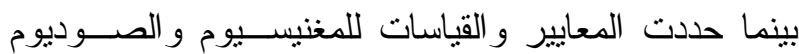

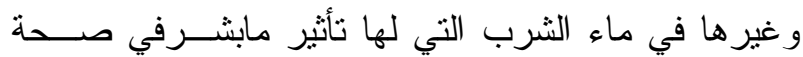
المستهلك (29).

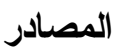

[1] V. T. C.Penna; S. A. M. Martins, and P. G. Mazzola. Identification of Bacteria and Purified Water During the Monitoring of Typical Water Purification System. BMC Public Health, 2002, Vol. (2).

$$
\begin{aligned}
& \text { الفتلاوي، يعرب فالح. دراسة نوعية مياه } \\
& \text { الثــرب لبعض مشاريع اسالة ماء بغداد. }
\end{aligned}
$$




$$
\begin{aligned}
& \text { [21] الزيدي، حامد مجيد. علم الاحياء المجهرية } \\
& \text { النظري. دار الكتب للطباعة و النشر، بغداد، الناء الناءيا } \\
& \text {. } 1988 \\
& \text { [22] بركات، نادية طارق . قياس ملوثات مياه الثرب }
\end{aligned}
$$

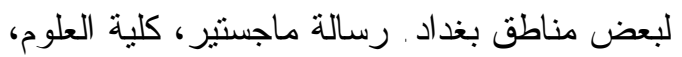

$$
\begin{aligned}
& \text { جامعة بغداد، } 2007 \text {. }
\end{aligned}
$$

[23] D. Zmirou, S. Rey, X. Courtois, J. P. Ferley, J. F. Blatier, P. Chevallier, J.Boudot., J. L. Potelon, and R. Mounir, Residual Microbiological Risk After Simple Chlorine Treatment of Drinking Ground Water In Small Community, 2007.

[24] G. A. Gagnon, J. L Rand, K. C. O.Learg, A. C. Rjgel, C. Chauret, and, R. C. Andrews Disinfectant Efficacy of Chlorine Dioxide in Drinking Water Biofilms. Water Res.vol. 39, 2005, pp.1809-1817.

[25] R. K. J. Al-Qaisi, Residual Chlorine Concentration In Baghdad Water Supplies, M.Sc., Thesis Building and Constriction, Uni Of Technology, 2005.

[26] M. J. Hammer, Water and Water Waste Technology, ( $3^{\text {rd }}$ Ed.), Prentice-Hall, Inc. Simon and Schuster Company, Engle Wood Cliffs, New J. Ersey,1996.

[27] حسن، بشرى خالد وشذى عبد الرزاق وأمال

رشيد فرحان، قياس كفاءة تعقيم مياه الثرب ونداب

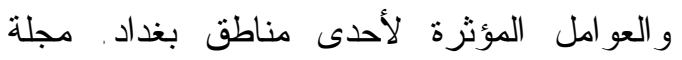

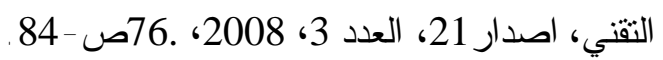

[28] R. L. Welcomme, Fisheries Ecology of Flood Plair, Reivers Longman Int. NewYork, 1979, Pp: 317.

[29] A. Ilyas, And S. Tanir, Assessment of Physico-Chemical and Biological Quality of Drinking Water in the Vicinity of Palosidrain Pasha Wav. Pakistan Journal of Applied Sciences,vol. 3, No.1, 2003, pp. 58-65.

\section{Abstract}

This study was performed in few locations in Baghdad city to evaluate estimate bacteriological contains of the potable water during October/2007 up to September/2009. Six region in AL-karhk side and Four in $\mathrm{Al}-$ Resafa side were selected randomly. The result shows that total count bacteria and coliform

[12] E. J Baron, and S. M. Finegold, Baily and Scott Diagnostic Microbiology. C. V. Mos By Company Toronto, 1990.

[13] J. G. Holt, N. R. Krieg, P. H. A Senth,. J. T. Staley, and S. T. C. Williams, Berges Manual of Determinative Bacteriology. $\left(19^{\text {th }}\right.$ Ed.) Williams and Wilkin .Company. Baltimore. USA, 1994, Pp 175-180.

[14] (ASTM), American Society for Testing Materials, Annual Book of ASTM (American Society for Testing Materials). Philadelphia, U.S.A. ,1989, Pp. 1110.

[15] H. L.Golterman, R. S. Clymo, and M. A. M. Dhnstad, Method For Physical and Chemical Analysis of Fresh Water. $\left(2^{\text {nd }} \cdot\right.$ Ed.). IBP. Blackwells Scientific Publication, Osney Mead, Oxford, Hand No. 8, 1978, 213 Pp.

$$
\begin{aligned}
& \text { [16] التميمي، عبد الناصر عبداله مهدي. أستخدام } \\
& \text { الطحالب أدلة إصيانية لتلوث الجزء الأشعل من } \\
& \text { نهر ديالى بالمو اد العضوية. أطروحة دكثور اه، } \\
& \text { كلية التربية - أبن الهيثم، جامعة بغداد، } 2006 . \\
& \text { [17] الميالي، إيثار كامل وعلي نوري عبد، تقييم } \\
& \text { النوعية المايكروبية لمباه الثرب الموزعة من } \\
& \text { مجمع الفتح المبين. مجلة علوم المستصرية، }
\end{aligned}
$$

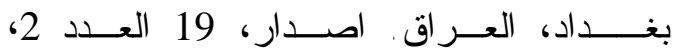

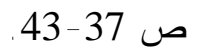

$$
\begin{aligned}
& \text { [18] صبري، أنمار وهبي ومحمد حسن يونس وحسن } \\
& \text { هندي سلطان. التلوث البكنيري في نهر الفرات. } \\
& \text { مجلة أبحاث البيئة و التتمية المستدامة. منظمة } \\
& \text { الطاقــة الذريـــة، اصدار ،4 العــــــد } 1 \text { ، 2001، } \\
& \text { ص. } 30 \text { - } 30 \\
& \text { [19] تركي، أحمد محمد . در اسة المحتوى المايكروبي } \\
& \text { وبعض العوامل البيئية لمياه القاطع الثمالي } \\
& \text { للمصب العام. رسالة ماجستير، كلية العلوم، } \\
& \text { جامعة الانبار ، } 2001 \text { ( ) } \\
& \text { [20] الحسني، سعد أبر اهيم جاسم. المؤثزات البيئية } \\
& \text { للمياه المترشحة في منطقة الدورة - بغداد ـ رسالة } \\
& \text { ماجستير ، كلية العلوم، جامعة بغداد، } 2003 .
\end{aligned}
$$


boundary in all Baghdad to be less than (600) $\mathrm{ml} /$ liter.

The Electrical Conductivity hang about it's normal rate to (WHO) but the domestic storage water go beyond it's limit to reach $2259 \mu \mathrm{s} / \mathrm{cm}$ in Al Karhk. bacteria were increase in domestic storage water in all regions during summer.

There number were high than up normal to those of standard criteria .Also the bacteria Salmonella typhi, was found in Issala of in $\mathrm{Al}$-Resafa side during summer. The chloride readings confirm that it's less than the accepted 